ФОРМУВАННЯ ПРОФЕСІЙНОЇ КУЛЬТУРИ У МАЙБУТНІХ УЧИТЕЛІВ ФІЗИЧНОЇ КУЛЬТУРИ ЗАСОБАМИ РИТМІКИ І ХОРЕОГРАФІЇ

\title{
FORMATION OF PROFESSIONAL CULTURE IN FUTURE TEACHERS OF PHYSICAL CULTURE BY MEANS OF RHYTHMIC AND CHOREOGRAPHY
}

Стаття присвячена проблемі формування
у студентів педагогічних вишів професійної
культури засобами ритміки і хореографії.
Визначено, що професійна культура - че
частина загальної культури особистості
і є складним інтег'ративним динамічним
утворенням у цілісній структурі особис-
тості, що характеризує всю сукупність
відносин у сфеері педагогічної діяльності
та відповідний розвиток індивідуальних
професійно значущих здібностей, розумо-
вих, психологічних та орізичних якостей,
мотиваційної сфрери, забезпечуючи високу
якість і позитивне ставлення до профресій-
ної діяльності. 3'ясовано, що джерелом розвитку професійної культури студентів, особистісних властивостей і якостей є суспільний досвід, нагромаджений попередніми поколіннями людей у процесі їхної пізнавальної, трудової, соціальної, моральної, естетичної, творчої діяльності. Джерела, що сприяють становленню організованої особистості вчителя, містять як у ссрері суб'єктивного, так і у сорері зовнішніх впливів. Зовнішне соціальне середовище впливає на розвиток здібностей до самоорганізації через мотиваційну среру особистості. Запропонована методика проведення занять з ритміки і хореографрії для студентів з метою фрормування профресійної культури майбутнього фрахівця. Прочес навчання поділено на три етапи, кожен з яких мав свою мету, спрямованість і завдання. На першому етапі навчання здійснювали ознайомлення 3 танцювальним рухом в інваріантному вигляді. Надавалося зрозуміле роз'яснення, переважно в образноігровому вигляді. На другому етапі навчання спрямовувалось на виконання танцювального руху, яке включало розучування руху, наступне закріплення сфрормованої навички та якісне удосконалення сорормованої на більш високому музично-руховому, емоційнообразному рівні. На третьому етапі зусилля спрямовувались на вдосконалення рухово навички як творче виконання танцювального руху у варіативному варіанті. Процес просресійного становлення особистості студентів був пов'язаний з розвитком особистісних якостей, становлення самокритичності і вимог до себе.
Ключові слова: просресійна культура, студент, ритміка, хореограсрія, навчання.

The article is devoted to the problem of formation of professional culture in students of pedagogical universities by means of rhythmics and choreography. It is determined that professional culture is part of the general culture of personality and is a complex integrative dynamic formation in the holistic structure of personality, which characterizes the whole set of relations in the field of teaching and the corresponding development of individual professionally significant abilities, mental, psychological and physical qualities, motivational sphere. quality and positive attitude to professional activity.

It was found that the source of development of professional culture of students, personal qualities and qualities is the social experience accumulated by previous generations of people in the process of their cognitive, labor, social, moral, aesthetic, creative activities. Sources that contribute to the formation of an organized personality of the teacher contain both in the sphere of subjective and in the sphere of external influences. The external social environment affects the development of abilities for selforganization through the motivational sphere of the individual. The method of conducting classes in rhythmics and choreography for students in order to form the professional culture of the future specialist is proposed. The learning process is divided into three stages, each of which had its own purpose, focus and objectives. At the first stage of training the acquaintance with dance movement in invariant kind was carried out. A clear explanation was provided, mostly in the form of a game. In the second stage, the training was aimed at performing a dance movement, which included learning the movement subsequent consolidation of the formed skill and qualitative improvement of the formed at a higher musical-motor, emotional-image level. At the third stage, efforts were aimed at improving motor skills as a creative performance of dance movement in a variable version. The process of professional development of students personality was associated with the development of personal qualities, self-criticism and self-demands. Key words: professional culture, student, rhythmics, choreography, training.
Постановка проблеми. Сучасна освіта потребує від фахівця з фрізичної культури і спорту володіння уміннями організовувати та здійснювати навчально-виховну роботу 3 учнями закладів загальної середньої освіти з метою фрормування їх фрізичної культури, сприяння гармонійному розвитку особистості, формування позитивних рис характеру, зміцнення здоров'я, вдосконалення фрізичної та психологічної підготовки до активного життя.

Майбутній учитель сьогодення покликаний бути носієм накопичених культурою новітніх загальнолюдських цінностей, всебічно знати наці- ональні, культурні, історичні традиції свого народу. Соціальний обов'язок молодої людини виявляється в ії̈ здатності до творчого засвоєння цінностей культури, до постійного культурного самовдосконалення, до свідомого переборювання внутрішньої душевної інерції [5, с. 23].

Завдання вчителя 3 розвиненою педагогічною культурою полягає в тому, щоб навчити учня усвідомлювати мотиви своєї поведінки, тобто формувати цілі й програму діяльності, передбачати ії результати. Усвідомлення мотиву викликає почуття особистої зацікавленості та бажання 
доводити розпочату справу до логічного завершення. Ґрунтуючись на пізнавальній потребі учня, вчитель може розвивати інтерес до навчального предмета, до знань, до світу, пов'язуючи цей інтерес із певними цінностями, що висуваються суспільством. Пізнавальний інтерес як основа мотивації навчання, на нашу думку, найкраще формується в умовах проблемної ситуації. Дійсно, пошук розв'язання передбачає вибір, який вимагає додаткову інформацію, наближує навчальну діяльність до наукової, дослідницької. Але додаткова інформація має цінність лише тоді, коли вона цікава, актуальна, допомагає засвоїти навчальний матеріал у контексті, що має для учня своєрідний індивідуальній смисл. Організація такої роботи свідчить про високий професіоналізм та високу профресійну культуру вчителя [2].

Профресійна культура як частина загальної культури особистості є складним інтеґративним динамічним утворенням у цілісній структурі особистості, що характеризує всю сукупність відносин у сорері педагогічної діяльності та відповідний розвиток індивідуальних профресійно значущих здібностей, розумових, психологічних та фрізичних якостей, мотиваційної сфери, забезпечуючи високу якість і позитивне ставлення до професійної діяльності [5, с. 52].

Аналіз останніх досліджень і публікацій. Проблема підготовки майбутніх учителів до професійної діяльності хвилювала не одне покоління науковців, а саме видатних діячів П.П. Блонського, І.Ф. Гербарта, О.С. Макаренка, І.Г. Песталоцці, К.Д. Ушинського, С.Т. Шацького та багатьох інших. У працях видатних фрахівців педагогіки B.І. Горової, Л.М. Митіна, В.В. Радула, В.А. Сластеніна та інших дослідників виділена структура педагогічної діяльності та шляхи її становлення.

Аналіз науково-педагогічної літератури дозволив з'ясувати, що профресійна культура вчителя у поєднанні 3 педагогічною реалізуються багато в чому за допомогою педагогічної вимогливості. Педагогічна вимогливість - це глибоко продумана лінія поведінки педагога-вихователя, яка не містить формалізму, догматизму, деспотизму у професійних діях. Вимогливість - це вміння вчителя підходити до оцінки особистості учня, його поведінки, знань та умінь на основі найвищих суспільних критеріїв, постійного усвідомлення необхідності вдосконалення особистості вихованця, його ерудиції, культури, моральності [3]. На нашу думку, зміст педагогічної культури вчителя має включати такі профресійно-етичні погляди:

1. Вимогливість до учнів як міра поваги до них та як показник реалізації цієї поваги.

2. Повага до думки учнів про вчителя як основа вимогливості учителя до себе.

3. Терпимість до самостійності думки, почуттів і вчинків учнів, уміння не забороняти їх навіть тоді, коли вони з погляду вчителя є неправильними.
4. Довіра до кожного учня, до його думок та вчинків.

Для плідної профресійної діяльності у процесі співробітництва вчителя 3 учнями педагогу необхідна мобілізація інтелекту, волі, моральних зусиль, організаторських здібностей та вміле оперування засобами фрормування моральних, інтелектуальних і духовних якостей в учнів.

Мета роботи полягає у визначенні особливостей фрормування професійної культури майбутніх учителів фрізичної культури засобами ритміки і хореографрії. Мета дослідження зумовила визначення таких завдань:

- теоретично дослідити проблему змісту професійної культури фрахівця галузі освіти;

- уточнити зміст педагогічної культури майбутнього вчителя фрізичної культури;

- виявити вплив занять з ритміки і хореографії на фрормування педагогічної культури майбутнього вчителя фрізичної культури.

Виклад основного матеріалу. 3 огляду на ступеневість вищої освіти, фрахова підготовка студентської молоді диференціюється за відповідними освітньо-кваліфікаційними рівнями з урахуванням специфіки спеціальностей.

Зміст фрахової підготовки реалізується через інтегровані навчальні курси, що забезпечує системність у вивченні навчальних дисциплін, сприяє уникненню дублювання навчального матеріалу, зміцненню міжпредметних зв'язків та поліпшенню організації навчального процесу і запровадженню новітніх технологій навчання.

Метою практичної підготовки є поглиблення теоретичних знань на основі практичного навчання; формування у майбутніх педагогів умінь та навичок практичної діяльності в навчально-виховних закладах; фрормування та розвиток профресійнопедагогічних умінь і навичок; оволодіння сучасними методами і фрормами педагогічної діяльності, новими прогресивними технологіями навчання; формування творчого дослідницького підходу до педагогічної діяльності.

Джерелом розвитку професійної культури студентів, особистісних властивостей і якостей $є$ суспільний досвід, нагромаджений попередніми поколіннями людей у процесі їхньої пізнавальної, трудової, соціальної, моральної, естетичної, творчої діяльності. Джерела, що сприяють становленню організованої особистості вчителя, містять як у сорері суб'єктивного, так і в сорері зовнішніх впливів. Зовнішнє соціальне середовище впливає на розвиток здібностей до самоорганізації через мотиваційну сореру особистості. Тому самоорганізацію особистості вчителя ми трактуємо як його професійну якість, що має інтелектуально-вольову спрямованість та розвивається у діяльності [3, с. 68].

Від учителя, від його майстерності і компетентності залежатиме, якими стануть його учні. Будь-яка компетентність, зокрема й педагогічна, 
пов'язана із високим рівнем самореалізації індивідуальних особистостей - 3 індивідуальним стилем діяльності. Щоб сформувати педагогічну компетентність, необхідно фрормувати індивідуальний стиль діяльності. Важливою якістю праці вчителя має бути її творчий характер, інтеграція педагогічної теорії та практики. Педагогічна теорія допомагає вчителеві не лише пояснювати педагогічні фракти та явища, але й визначати науково обґрунтовані способи роботи

Особливого значення у діяльності майбутнього вчителя фрізичної культури в сучасних умовах набуває поєднання фрундаментальної освіти та глибокого опанування наукових основ професійно-педагогічної діяльності з практичним оволодінням нею, з формуванням практичних умінь та навичок. Високий професіоналізм учителя в обраній галузі праці у поєднанні його з активною діяльністю в різних сорерах духовного та суспільного життя, $з$ одного боку, сприяє всебічному розвитку фрахівця, а з іншого, допомагає ефективніше працювати за спеціальністю, підвищувати якість педагогічної діяльності.

Актуальною у цьому контексті $€$ проблема набуття студентами фрізкультурних знань, культури рухів, фрормування пріоритету здоров'я, що має посідати одне з чільних місць у системі найвищих ціннісних орієнтацій людей різних соціальних і вікових груп і на цій основі поліпшення фрізичного стану. Успішне розв'язання цієї проблеми можливе тільки за умови цілеспрямованого комплексного розв'язання завдань 3 виховання профресійної культури особистості, студента засобами ритміки і хореографії.

У процесі дослідження визначено, що вплив мистецтва завжди потребує від особистості співтворчості, активного естетичного реагування, осягнення його художньої цінності. Особистість відтворює у своїй свідомості художній образ, завдяки чому мистецтво й виконує головне своє завдання - розвиває духовний потенціал людини, її чуттєво-емоційний досвід.

Основна вимога хореографрічної освіти - естетичнеіморальне вихованнязадопомогоювивчення й усвідомленого сприйняття кращих зразків світової хореографрічної культури [4]. Завдання, які постають на заняттях з ритміки і хореографії, полягають у формуванні у студентів інтересу до мистецтва, здатності розуміти його і співпереживати; виховуванні естетичних смаків на основі вивчення кращих зразків народної творчості і класичного мистецтва; фрормуванні теоретичних і практичних навичок й умінь в процесі навчання; розширенні художнього кругозору студентів.

В експериментальному дослідженні нами було визначено три етапи. На першому етапі навчання здійснювали ознайомлення 3 танцювальним рухом в інваріантному вигляді. Провідного зна- чення набував виразний, повноцінний, музично зумовлений показ руху педагогом. Через зразковий показ студента орієнтували на засвоєння основного принципу руху (галоп - польотний; біг стрімкий). На цьому етапі відбувалося сприймання студентами певного еталону виконання рухів. Надавалося зрозуміле роз'яснення, переважно в образно-ігровому вигляді.

На другому етапі навчання спрямовувалось на виконання танцювального руху, яке включало розучування руху, наступне закріплення сорормованої навички та якісне удосконалення сорормованої на більш високому музично-руховому, емоційно-образному рівні. Цей етап найбільш тривалий у часі. Рух може розучуватися двома основними прийомами: спочатку цілісно і далі 3 подальшим удосконаленням його елементів; або розучування відбувається від елементів - до засвоєння руху у цілісному вигляді.

На третьому етапі зусилля спрямовувались на вдосконалення рухової навички як творче виконання танцювального руху у варіативному варіанті (з визначеною кількістю варіантів).

Проведення занять з ритміки і хореографрії має свою специфіку. Пропонуючи рухи під музику, педагог не повинен рахувати, тому що це відволікає студентів, саме для розвитку музикальності студенти повинні уважно вслухуватися в музику. Іноді, якщо вони виконують рухи неточно, педагог може прорахувати потрібний музичний розмір, чи надати цю можливість самим студентам. Необхідною умовою розвитку музикальності студентів є розмаїтість музичного супроводу на заняття з ритміки і хореографрії, а також дисциплінах практичного циклу.

Досвідчені педагоги радять до кожному новому занятті, складеному педагогом, давати новий музичний матеріал. Це створить у студентів уяву про існування в танці, музиці визначеної народності різних музичних розмірів, інтонацій, темпів $[1 ; 3 ; 6]$.

Основними прийомами, якими педагог користується для пояснення правил виконання, а також образної, емоційної сторони, є показ і розповідь. Показ особливо важливий у поясненні техніки виконання рухів і порядку виконання комбінації. Нові рухи необхідно показувати уповільнено кілька разів, поки студенти не засвоять правила виконання, і обов'язково супроводжувати показ докладним усним поясненням. Комбіновані вправи показуються у звичайному темпі, один раз - під рахунок, і другий раз - під музику. Багаторазові виконання комбінації педагогом активізують увагу і зорову пам'ять студентів, розвитку яких повинна приділятися велика увага, тому що навчання мистецтву танцю відбувається більшою мірою через зорове сприйняття. Показ викладача повинний допомогти студентам засвоїти насамперед єдині технічні прийоми виконання, тому він повинний бути точним, музично вірним. Іноді показ викла- 
дача може бути прикладом виконавської манери. Але він не повинен народжувати наслідувачів в особі студентів, він повинен сприяти розвитку їхньої творчої індивідуальності.

Поряд 3 показом, розповідь, пояснення педагога має найважливіше значення в процесі навчання народно-сценічному танцю. Мова яскрава, образна, емоційна незамінна, якщо вона звернена до творчої уяви студентів, до змісту музики і танцю, до його образності, якщо вона стосується національної своєрідності хореографії, характеру, побуту визначеного народу.

Для успішної роботи викладача і його вихованців винятково важливі методичні зауваження. Вони можуть бути звернені до одного студента і до всієї групи одночасно, тобто можуть бути індивідуальні і загальні. Найчастіше такі зауваження здійснюються перед початком вправи чи під час її виконання. За своїм змістом зауваження можуть стосуватися техніки виконання, музикальністю, емоційно-танцювальної виразності, здатності передавати національний колорит танцю. За фрормою викладу вони повинні бути короткими, ясними, логічно послідовними. Великі пояснення на практичних заняттях приводять до неприпустимої втрати часу, розхолоджують студентів.

Важливою умовою успішного ходу заняття $€$ дотримання правильного його темпу. Основний критерій гарного темпу практичних занять - збереження високої працездатності студентів протягом всього заняття. За надто повільного темпу у студентів немає можливості привести в робочий стан усі м'язи, зберегти цей стан до кінця занять і розвити витривалість. За надто швидкого темпу студенти не встигають усвідомити методику навчання, з'являються ознаки розу-мової перевтоми: неуважність, повільна реакція на зауваження педагога. Темп заняття визначається темпом виконання кожної вправи і кожного етюду на середині залу, а також темпом їхньої змінюваності. На початку навчання повільний темп використо- вується як навчальний прийом, необхідний для правильного детального освоєння кожного руху. Надалі темп виконання рухів, темп заняття прискорюється, але розучування нових вправ завжди здійснюється повільно.

Висновок. Отже, з наведених рекомендацій 3 методики навчання і проведення занять ритмікою і хореографрією вибудовуються завдання навчально-педагогічної роботи з формування профресійної культури майбутніх учителів фрізичної культури. Знання і застосування на практиці наведених рекомендацій, а також досвід, творча захопленість допоможуть майбутнім педагогам оволодіти майстерністю своєї професії.

Для сучасної профресійної освіти вагоме значення має фрормування педагогічної, профресійної культури майбутніх учителів фрізичної культури, стимулювання у них творчого начала, здатності сприймати інновації та все те, що складає сутність профресійної компетентності фрахівця.

\section{БІБЛІОГРАФІЧНИЙ СПИСОК:}

1. Вільчковський Е.С., Денисенко Н.Г., Шевченко Ю.М. Інтеграція рухів і музики у фрізичному розвитку дітей. Тернопіль : Мандрівець, 2011. 128 с.

2. Пророков О.В. Танцювальні елементи на уроках фрізкультури та в позаурочній роботі. Тернопіль : Підручники та посібники, 2009. 64 с.

3. Ротерс Т.Т. Музыкально-ритмическое воспитание и художественная гимнастика. Москва : Просвещение, 1989. 175 с.

4. Шевчук А.C. Дитяча хореограсрія: програма та навчально-методичне забезпечення хореографічної діяльності дітей від 3 до 7 років. Київ : Шк. світ, 2011. $128 \mathrm{c}$

5. Шевченко І.Л. Формування профресійної культури майбутнього вчителя музики в позанавчальній діяльності : дис. ... канд. пед. наук : спец. 13.00.04 «Теорія і методика професійної освіти». Кіровоград, 2007. $230 \mathrm{c}$

6. Шевченко О.В., Шевченко А.О. Ритміка і хореографрія 3 основами гімнастики художньої : навчальний посібник. Кіровоград : Авангард, 2012. 252 с. 